\title{
Feeding by raphidophytes on the cyanobacterium Synechococcus sp.
}

\author{
Hae Jin Jeong ${ }^{1, *}$, Kyeong Ah Seong ${ }^{2}$, Nam Seon Kang ${ }^{1}$, Yeong Du Yoo ${ }^{1}$, \\ Seung Won Nam ${ }^{3}$, Jae Yeon Park ${ }^{4}$, Woongghi Shin ${ }^{5}$, Patricia M. Glibert ${ }^{6}$, \\ Desmond Johns ${ }^{6}$
}

\author{
${ }^{1}$ School of Earth and Environmental Sciences, College of Natural Sciences, Seoul National University, Seoul 151-747, \\ Republic of Korea \\ ${ }^{2}$ Saemankeum Environmental Research Center, Kunsan National University, Kunsan 573-701, Republic of Korea \\ ${ }^{3}$ Division of Electron Microscopic Research, Korea Basic Science Institute, 113 Gwahangno, Yuseong-gu, Daejeon 305-333, \\ Republic of Korea \\ ${ }^{4}$ Environment Energy Resource Institute, Advanced Institute of Convergence Technology, Suwon 443-270, Republic of Korea \\ ${ }^{5}$ Department of Biology, Chungnam National University, Daejeon 305-764, Republic of Korea \\ ${ }^{6}$ University of Maryland Center for Environmental Science, Horn Point Laboratory, PO Box 775, Cambridge, \\ Maryland 21613, USA
}

\begin{abstract}
We investigated feeding by the raphidophytes Chattonella ovata, C. subsalsa, Fibrocapsa japonica, and Heterosigma akashiwo on the cyanobacterium Synechococcus sp. To explore whether each species is able to feed on Synechococcus sp., we carefully observed inside target grazer cells using an epifluorescence microscope and tranbsmission electron microscope (TEM). We also explored the feeding behaviors of C. ovata and $H$. akashiwo on Synechococcus using high-resolution video microscopy. In addition, we measured ingestion rates of C. ovata, C. subsalsa and H. akashiwo on Synechococcus sp. as a function of prey concentration. We calculated grazing coefficients by combining the field data on abundances of $H$. akashiwo and co-occurring Synechococcus spp. with laboratory data on ingestion rates. Both $C$. ovata and $H$. akashiwo were able to ingest single Synechococcus cells. However, neither TEM nor video microscopy showed any Synechococcus cells inside or ingested by $F$. japonica. One to two ingested Synechococcus cells inside the protoplasm of $F$. japonica cells were very rarely observed. C. ovata and H. akashiwo engulfed a single Synechococcus cell captured by the mucus excreted from mucocysts. The ingestion rates of C. ovata, C. subsalsa, or H. akashiwo on Synechococcus increased continuously with increasing prey concentration at prey concentrations $\leq 4 \times$ $10^{6}$ to $5.5 \times 10^{6}$ cells ml $^{-1}$. At a given prey concentration, the highest ingestion rates of the raphidophytes on Synechococcus were 18.6 cells raphidophyte ${ }^{-1} \mathrm{~h}^{-1}$ for C. ovata, 20.5 cells raphidophyte ${ }^{-1} \mathrm{~h}^{-1}$ for C. subsalsa, and 3.9 cells raphidophyte ${ }^{-1} \mathrm{~h}^{-1}$ for $H$. akashiwo. The calculated grazing coefficients attributable to $H$. akashiwo on co-occurring Synechococcus spp. were up to $1.24 \mathrm{~d}^{-1}$. The results of the present study suggest that raphidophytes sometimes have a considerable grazing impact on populations of Synechococcus.
\end{abstract}

KEY WORDS: Chattonella spp. Fibrocapsa japonica $\cdot$ Graze $\cdot$ Heterosigma akashiwo $\cdot$ Harmful algal bloom $\cdot$ HAB $\cdot$ Ingestion $\cdot$ Red tide

\section{INTRODUCTION}

The raphidophytes Chattonella spp., Fibrocapsa japonica, and Heterosigma spp. are common red-tide organisms with worldwide distribution, excluding arctic waters (Smayda 1998, Edvardsen \& Imai 2006, Demir et al. 2008, Menden-Deuer et al. 2008). They are known to be harmful to other plankton (e.g. Clough \& Strom 2005) and fish (e.g. Hiroishi et al. 2005) and have often caused large-scale fish mortality rates in the 
waters of many countries (MacKenzie 1991, Honjo 1993, Imai et al. 1996, Bourdelais et al. 2002). The density of $H$. akashiwo sometimes exceeds 100000 cells $\mathrm{ml}^{-1}$ during red tides (Nagasaki et al. 1996, Jeong et al. 2005d), while that of Chattonella spp. or F. japonica sometimes exceeds 10000 cells ml$^{-1}$. Gill tissue damage is known to be the ultimate cause of fish death (Edvardsen \& Imai 2006). Reactive oxygen species, neurotoxins, and mucus have been suggested to be responsible for the gill tissue damage (Oda et al. 1997, Marshall et al. 2003, Bowers et al. 2006). However, Chattonella spp., F. japonica, and Heterosigma spp. are known to be important prey for mixotrophic and heterotrophic dinoflagellates (Tillmann \& Reckermann 2002, Jeong et al. 2003, Demir et al. 2008). Therefore, they play diverse roles in marine ecosystems.

The raphidophytes were previously considered to be exclusively autotrophic algae and thus were treated as phytoplankton. Therefore, there have been only a few studies on feeding by raphidophytes; Nygaard \& Tobiesen (1993) used isotope-labeled bacteria to show that Heterosigma akashiwo was able to ingest heterotrophic bacteria. Recently, Seong et al. (2006) used fluorescent-labeled bacteria (FLBs) and confocal microscopy to show that Chattonella ovata and H. akashiwo were able to feed on heterotrophic bacteria. However, in these studies the location through which the raphidophytes engulfed prey cells and feeding behaviors of raphidophytes were not explored. Raphidophytes have a very high number of chloroplasts (e.g. Hara \& Chihara 1987) and thus under light or epifluorescence microscopy, it is difficult to find openings on the raphidophyte cell body. Using a transmission electron microscope (TEM), raphidophytes have been observed to have 2 types of possible openings: (1) a funnel-shaped groove with 2 flagellae, and (2) mucocysts, which look like small openings when viewed from outside the cell surface (Vesk \& Moestrup 1987). The mucocysts secrete large amounts of mucus that sometimes kill fish (Imai et al. 1993). Thus, the mucocysts are candidates to be the location through which the raphidophytes engulf prey cells, and the roles of the mucocysts in raphidophyte feeding should be explored. To explore these topics, TEM and high-resolution video microscopy are necessary. In addition, what other prey raphidophytes feed on besides heterotrophic bacteria is also very important for understanding raphidophyte ecophysiology.

The photosynthetic cyanobacterium Synechococcus spp. is a ubiquitous prokaryote in marine environments (Landry et al. 1996, Maranon et al. 2003). It often dominates the abundance and/or the primary production of phytoplankton in both coastal and open ocean waters (Stal et al. 2003, Nielsen et al. 2004). The abundance of Synechococcus spp. often exceeds $10^{5} \mathrm{cells} \mathrm{ml}^{-1}$ and sometimes forms blooms (Glibert et al. 2004, Murrell \&
Lores 2004, Jeong et al. 2005d). Sunda et al. (2006) reported that some blooms dominated by Synechococcus spp. were harmful to diverse marine organisms such as seagrasses, spiny lobsters, and multiple sponge species. In ocean waters, Synechococcus spp. is thought to be one of the major contributors to $\mathrm{CO}_{2}$ and nutrient uptake from the ocean waters and in turn eventually from the atmosphere (Maranon et al. 2003). In addition, some Synechococcus spp. are known to conduct nitrogen fixation (Phlips et al. 1989, Herrero et al. 2001) and thus are able to survive in environments where the concentration of inorganic nitrogen is very low (Glibert et al. 2004, Sunda et al. 2006). In turn, they may play an important role as a nitrogen source for their predators. Therefore, the growth and mortality of Synechococcus spp. are important factors in understanding the cycling of materials in marine planktonic food webs.

Heterotrophic nanoflagellates and ciliates have long been known to be major grazers on Synechococcus spp. (Christaki et al. 1999, 2002, Agawin et al. 2004). However, many mixotrophic dinoflagellates have recently been shown to feed on Synechococcus spp. (Jeong et al. 2005a, Glibert et al. 2009). Raphidophytes have been reported to often co-occur with Synechococcus spp. and/or other cyanobacteria (Hayes \& Lewitus 2003, Livingston 2007, H. J. Jeong et al. unpubl. data). Therefore, there is a possibility that raphidophytes feed on Synechococcus spp. However, the interactions between raphidophytes and Synechococcus spp, and in particular the possible predator-prey relationships, are still poorly understood.

The goal of the present study was to understand the interactions between raphidophytes and Synechococcus spp. Our questions were: (1) Are raphidophytes able to feed on Synechococcus spp.? (2) If so, what are the feeding behaviors (mechanisms) they use? (3) What is the functional response of raphidophytes to the concentrations of Synechococcus spp.? (4) What is the grazing impact of raphidophytes on the population of Synechococcus spp. in natural environments?

To answer these questions we (1) investigated whether or not the common raphidophytes Chattonella ovata, Fibrocapsa japonica, and Heterosigma akashiwo are able to feed on Synechococcus sp. We observed inside the protoplasm of target raphidophyte cells using epifluorescence microscopy and TEM after adding living Synechococcus sp. cells; (2) explored the feeding behaviors of C. ovata and H. akashiwo on Synechococcus sp. using high-resolution video microscopy and several different types of microscope; (3) examined the functional responses of C. ovata and H. akashiwo to Synechococcus sp. as a function of Synechococcus sp. concentration in the laboratory; (4) estimated the grazing coefficients attributable to $H$. akashiwo on co-occurring Synechococcus sp. using our data for ingestion rates obtained from laboratory experiments and the abundances of 
predators and prey in the field. The results of the present study provide a basis for understanding the trophodynamics of raphidophytes, the interactions between raphidophytes and Synechococcus spp., and the bloom dynamics of these 2 components.

\section{MATERIALS AND METHODS}

Preparation of experimental organisms. Chattonella ovata (equivalent spherical diameter $[\mathrm{ESD}]=40.0 \mu \mathrm{m})$, Fibrocapsa japonica $(20.5 \mu \mathrm{m})$, and Heterosigma akashiwo $(11.0 \mu \mathrm{m})$ used in the experiments on feeding occurrence (Expt 1), feeding behavior (Expt 2), and effects of prey concentration (bottle incubation, Expt 3) were grown at $20^{\circ} \mathrm{C}$ and 30 to 31 salinity in enriched $\mathrm{f} / 2$ seawater medium (Guillard \& Ryther 1962) without silicate under a $14 \mathrm{~h}$ light:10 h dark cycle of $30 \mu \mathrm{E} \mathrm{m} \mathrm{m}^{-2} \mathrm{~s}^{-1}$ (Table 1). Synechococcus sp. (GenBank accession no. DQ023295; $\mathrm{ESD}=\mathrm{ca} .1 \mu \mathrm{m})$ were grown at $20^{\circ} \mathrm{C}$ and 30 to 31 salinity in enriched $\mathrm{f} / 2$ seawater medium under a $14 \mathrm{~h}$ light:10 h dark cycle of $30 \mu \mathrm{E} \mathrm{m}^{-2} \mathrm{~s}^{-1}$ of cool white fluorescent light. ESDs were measured with an electronic particle counter (Coulter Multisizer II). Cultures in their exponential growth phase were used for these feeding experiments.

The Chattonella subsalsa (strain CCMP 2191; ESD = $36.5 \mu \mathrm{m}$ ) cultures used in the ${ }^{15} \mathrm{~N}$ studies (Expt 4) were obtained from the Provasoli-Guillard National Center for Culture of Marine Phytoplankton, Bigelow Laboratory, West Boothbay Harbor, Maine, USA. Maintenance cultures were grown in 32 salinity and enrichment solution artificial seawater (ESAW) medium (Harrison et al. 1980) under a $14 \mathrm{~h}$ light:10 h dark cycle of $200 \mu \mathrm{E} \mathrm{m}^{-2} \mathrm{~s}^{-1}$. A monoculture of Synechococcus sp. in late exponential growth phase (strain CCMP 1768 originally isolated from the Gulf of Mexico and obtained from Bigelow Laboratory) was used for Expt 4.

Feeding occurrence. Expt 1 was designed to investigate whether or not each raphidophyte species was able to feed on Synechococcus sp. We observed Syne- chococcus sp. cells inside the predators using epifluorescence microscopy and TEM after adding living Synechococcus sp.

A dense culture of each raphidophyte species, maintained in $\mathrm{f} / 2$ medium and growing photosynthetically in the exponential growth phase and incubated under a $14 \mathrm{~h}$ light:10 h dark cycle of $30 \mu \mathrm{E} \mathrm{m}^{-2} \mathrm{~s}^{-1}$, was transferred to a 11 polycarbonate (PC) bottle containing freshly filtered seawater. Three $1 \mathrm{ml}$ aliquots were then removed from the bottle and examined using a compound microscope to determine the raphidophyte concentration.

For observation of Synechococcus sp. under an epifluorescence microscope, the initial concentrations of each raphidophyte predator (ca. 2000 to 10000 cells $\mathrm{ml}^{-1}$ ) and Synechococcus sp. (ca. $6 \times 10^{6}$ to $7 \times 10^{6}$ cells $\mathrm{ml}^{-1}$ ) were established using an autopipette to deliver a predetermined volume of culture with a known cell density to the experimental bottles. Triplicate $42 \mathrm{ml} \mathrm{PC}$ bottles (mixtures of raphidophyte predator and Synechococcus sp.) and triplicate predator control bottles (containing only the raphidophyte) were set up at a single prey concentration for each raphidophyte predator. The bottles were filled to capacity with freshly filtered seawater, capped, and then placed on a plankton wheel rotating at $0.9 \mathrm{rpm}$ at $20^{\circ} \mathrm{C}$ under continuous illumination of $30 \mu \mathrm{E} \mathrm{m} \mathrm{m}^{-2} \mathrm{~s}^{-1}$ for incubation $<12 \mathrm{~h}$ (Chattonella ovata and Heterosigma akashiwo) or a $14 \mathrm{~h}$ light:10 h dark cycle of $30 \mu \mathrm{E} \mathrm{m}^{-2} \mathrm{~s}^{-1}$ for incubation $>12$ h (Fibrocapsa japonica). After 5, 10, 30, and $60 \mathrm{~min}$ and $4 \mathrm{~h}$ incubation for $C$. ovata and $H$. akashiwo, which fed on prey cells very well, and 5, 10, 30, and $60 \mathrm{~min}$ and $4,12,24,48$, and $72 \mathrm{~h}$ incubation for $F$. japonica, which rarely fed on Synechococcus sp. cells, a $10 \mathrm{ml}$ aliquot was removed from each bottle and then fixed with formalin (final conc. $=4 \%$ ). The fixed aliquots were filtered onto $5 \mu \mathrm{m}$ pore-sized, $25 \mathrm{~mm}$ PC white membrane filters, and the concentrated cells on the membranes were then observed under an epifluorescence microscope (Zeiss-Axiovert 200M) with green-light excitation at a magnification of $1000 \times$ to determine whether or not each raphidophyte predator

Table 1. Sampling location and date and water temperature (Temp.) and salinity for isolation of each species. ESD: equivalent spherical diameter, na: not available, DE: Delaware, USA

\begin{tabular}{|c|c|c|c|c|c|c|}
\hline Organism & $\mathrm{ESD}(\mu \mathrm{m})$ & Location & Date & Temp. $\left({ }^{\circ} \mathrm{C}\right)$ & Salinity & Source/strain \\
\hline Chattonella ovata & 40.0 & Off Saemankeum, Korea & Sep 99 & 25.5 & 31.3 & Seong et al. (2006) \\
\hline C. subsalsa & 36.5 & Indian River Bay, DE, USA & Aug 01 & na & na & CCMP 2191 \\
\hline Fibrocapsa japonica & 20.5 & $\begin{array}{l}\text { Hobson's Bay, Melbourne, } \\
\text { Australia }\end{array}$ & Jul 98 & na & na & CCMP 1661 \\
\hline Heterosigma akashiwo & 11.0 & Keum Estuary, Korea & May 01 & 16.0 & 27.7 & Jeong et al. (2003) \\
\hline $\begin{array}{l}\text { Synechococcus sp. } \\
\text { (GenBank accession } \\
\text { no. DQ023295) }\end{array}$ & 1.0 & East China Sea & Oct 03 & 22.6 & 31.9 & Jeong et al. (2005a) \\
\hline Synechococcus sp. & 1.0 & Gulf of Mexico & Jun 95 & na & na & CCMP 1768 \\
\hline
\end{tabular}


was able to feed on Synechococcus sp. Pictures showing ingested Synechococcus sp. cells inside each raphidophyte predator cell were taken using a digital camera (Zeiss AxioCam MRc5) on the microscope at a magnification of $1000 \times$.

For observations using TEM, living Synechococcus sp. cells were added into each of three $270 \mathrm{ml}$ PC bottles (final conc. $=$ ca. $7 \times 10^{6}$ cells ml ${ }^{-1}$ ); each contained a target raphidophyte of concentration 2000 to 10000 cells $\mathrm{ml}^{-1}$. One 'target prey only' control bottle and 1 raphidophyte control bottle (without added prey) were set up for each experiment. The bottles were filled to capacity with freshly filtered seawater, capped, and then placed on a plankton wheel rotating at $20^{\circ} \mathrm{C}$ under a $14 \mathrm{~h}$ light: $10 \mathrm{~h}$ dark cycle of $30 \mu \mathrm{E} \mathrm{m}^{-2} \mathrm{~s}^{-1}$. At the beginning, and after 1,3 , and 5 d incubation periods, the contents of 1 experimental bottle from each interval were distributed into five $50 \mathrm{ml}$ centrifugal tubes and then concentrated at $1610 \times g$ for 10 min using a centrifuge (Vision Centrifuge VS-5500). Five pellets from the 5 centrifugal tubes were then transferred into $1.5 \mathrm{ml}$ tubes and fixed for $1.5 \mathrm{~h}$ in $4 \%(\mathrm{w} / \mathrm{v})$ glutaraldehyde in a culture medium. Afterwards, the fixative was removed and the pellets were rinsed using a $0.2 \mathrm{M}$ cacodylic acid/sodium salt solution ( $\mathrm{pH}$ 7.4). The pellet was then embedded in agar. After several rinses with the medium, the cells were post-fixed in $1 \%(\mathrm{v} / \mathrm{v})$ osmium tetroxide in deionized water. Dehydration was accomplished using a graded ethanol series $(50,60,70,80,90$, and $100 \%$ ethanol, followed by two $100 \%$ ethanol steps). The material was embedded in Spurr's low-viscosity resin (Spurr 1969). Sections were obtained with an RMC MT-XL ultramicrotome (Boeckeler Instruments) and post-stained with $3 \%(\mathrm{w} / \mathrm{v})$ aqueous uranyl acetate followed by lead citrate. The stained sections were viewed with a JEOL-1010 electron microscope.

Feeding behavior. Expt 2 was designed to investigate the feeding behavior of Chattonella ovata and Heterosigma akashiwo on Synechococcus sp. We did not conduct this experiment with Fibrocapsa japonica because in Expt 1, this species was revealed to very rarely feed on Synechococcus sp. The feeding behavior of C. ovata and H. akashiwo on living Synechococcus sp. was observed under light and epifluorescence microscopes with a high-resolution video system. In particular, we explored how each raphidophyte captures prey cells, how many prey cells are captured simultaneously, and where the raphidophytes engulf the prey.

A dense culture of Chattonella ovata, Heterosigma akashiwo, and living Synechococcus sp. was added to triplicate $42 \mathrm{ml} \mathrm{PC}$ bottles (final conc. of C. ovata / Synechococcus sp. $=2000 / 7 \times 10^{6}$; final conc. of $H$. akashiwo / Synechococcus sp. $=10000 / 7 \times 10^{6}$ ). The bottles were filled to capacity with freshly filtered seawater, capped, and then placed on a plankton wheel rotating at $20^{\circ} \mathrm{C}$ under continuous illumination of $30 \mu \mathrm{E}$ $\mathrm{m}^{-2} \mathrm{~s}^{-1}$. The bottles were incubated for $1,2,4$, and $6 \mathrm{~h}$. A $0.1 \mathrm{ml}$ aliquot was transferred onto a microscope slide and a cover glass was then placed. We monitored the behavior of $>300$ raphidophyte cells for each predator with respect to the living prey, using differential interference contrast (DIC) optics under an inverted epifluorescence microscope at a magnification of 400 to $1000 \times$. The feeding process of the raphidophyte was recorded using a video analyzing system (Sony DXC-C33) and also a digital camera (Zeiss AxioCam MRc5).

Effects of prey concentration. Expts 3 and 4 were designed to investigate the ingestion rates of Heterosigma akashiwo and Chattonella ovata (or C. subsalsa) on Synechococcus sp. as a function of prey concentration. Two different methods were used for these experiments; the first method (Expt 3) was measuring ingestion rates by comparing the concentrations of the raphidophyte predator and Synechococcus sp. between the experimental and control bottles. This method was used for H. akashiwo and C. ovata. The second method (Expt 4) was measuring ingestion rates using the ${ }^{15} \mathrm{~N}$ isotope method as in Glibert et al. (2009). This method was used for C. subsalsa.

In Expt 3, a dense culture of each raphidophyte predator (ca. 5000 cells ml $^{-1}$ for Chattonella ovata and ca. 100000 cells ml ${ }^{-1}$ for Heterosigma akashiwo) maintained in $\mathrm{f} / 2$ medium and growing photosynthetically in the exponential phase under a $14 \mathrm{~h}$ light:10 h dark cycle of $30 \mu \mathrm{E} \mathrm{m}^{-2} \mathrm{~s}^{-1}$ was transferred into a 11 PC bottle. Three $1 \mathrm{ml}$ aliquots from the bottle were counted using a compound microscope to determine the cell concentrations of the raphidophyte predator, and the cultures were then used to conduct the experiments.

The initial concentrations of Chattonella ovata (or Heterosigma akashiwo) and live Synechococcus sp. were established using an autopipette to deliver predetermined volumes of known cell concentrations to the bottles. Triplicate $42 \mathrm{ml}$ PC experimental bottles (containing mixtures of predator and prey), prey control bottles (containing prey only), and predator control bottles (containing predator only) were also established. Ten $\mathrm{ml}$ of $\mathrm{f} / 2$ medium were added to all the bottles, which were then filled to capacity with freshly filtered seawater, capped, placed on plankton wheels rotating, and incubated at $20^{\circ} \mathrm{C}$ under a $14 \mathrm{~h}$ light:10 h dark cycle of $30 \mu \mathrm{E} \mathrm{m}^{-2} \mathrm{~s}^{-1}$. To determine the actual initial predator and prey densities (cells $\mathrm{ml}^{-1}$ ) at the beginning of the experiment and after $24 \mathrm{~h}$ incubation, a $4 \mathrm{ml}$ aliquot was removed from each bottle and fixed with $5 \%$ Lugol's solution, while another $4 \mathrm{ml}$ aliquot was fixed with $4 \%$ formalin. All or $>300$ predator cells, fixed in Lugol's solution, in three $1 \mathrm{ml}$ Sedgwick-Rafter counting chambers were enumerated. The aliquots fixed with formalin were filtered onto $0.2 \mu \mathrm{m}$ pore 
sized, $25 \mathrm{~mm}$ PC black membrane filters and then the concentrated cells on the membranes were observed under an epifluorescence microscope (Olympus BX51) with green-light excitation at a magnification of $1000 \times$ to determine the concentration of Synechococcus sp. The actual initial predator (and prey) concentrations were 22 to 2330 cells ml-1 (4220 to 3880680 cells ml $^{-1}$; 8 prey concentrations) for C. ovata and 102 to 12780 cells ml ${ }^{-1}$ (6360 to 4608780 cells ml ${ }^{-1} ; 7$ prey concentrations) for $H$. akashiwo. We tried to minimize the concentration of heterotrophic bacteria in the $C$. ovata and $H$. akashiwo cultures using diverse antibiotics and/or mechanical filtering. Among the antibiotics (chloramphenicol, gentamicin, kanamycin, cephalothin, norfloxacin, erythromycin, ciprofloxacin), chloramphenicol was the most effective. The final concentration of $15 \mu \mathrm{g} \mathrm{ml}^{-1}$ was an optimal concentration in which $>50 \%$ of the heterotrophic bacteria were killed, while there was no apparent harmful effect on the swimming pattern, morphology, and abundance of C. ovata. We also reduced the abundance of heterotrophic bacteria inside a culture of $H$. akashiwo by removing waters from the culture of the raphidophyte using a siphon and 5 or $10 \mu \mathrm{m}$ meshed net and then adding autoclaved seawater to the culture. However, there were still some heterotrophic bacteria in the culture. We counted the actual initial concentration of heterotrophic bacteria using the same method as Seong et al. (2006). The actual initial concentrations of heterotrophic bacteria in the $C$. ovata and $H$. akashiwo incubation bottles were $<13 \%$ and $<18 \%$ of Synechococcus sp., respectively.

Ingestion and clearance rates were calculated using the equations of Frost (1972) and Heinbokel (1978).

In Expt 4, $1 \mathrm{~d}$ prior to the grazing experiments, a monoculture of Synechococcus sp. in late exponential growth phase (strain CCMP 1768) was labeled with $10 \mu \mathrm{mol}{ }^{15} \mathrm{~N}$-urea and incubated for $24 \mathrm{~h}$ to ensure uniform isotope labeling. The amount of isotope label in the Synechococcus sp. culture was subsequently determined by mass spectrometry. The Chattonella subsalsa cultures (N-starved, in late exponential growth phase) were gently transferred to new $60 \mathrm{ml}$ culture flasks and an inoculum of the labeled Synechococcus sp. was added. The initial concentration of C. subsalsa was $3.8 \times 10^{4}$ cell $\mathrm{ml}^{-1}$. Six different cell concentrations of ${ }^{15} \mathrm{~N}$-labeled Synechococcus sp. were used, from $1.09 \times$ $10^{5}$ to $5.4 \times 10^{6}$ cells $\mathrm{ml}^{-1}$ and no prey (prey control). The flasks were held in a constant temperature incubator for $24 \mathrm{~h}$, on a $14 \mathrm{~h}$ light:10 h dark cycle. After incubation, the contents of the flasks were filtered through pre-combusted filters (GF/D, nominal pore size $2.7 \mu \mathrm{m}$ ) that retained the raphidophyte cells and possibly some of the Synechococcus sp. cells (if attached to the raphidophytes). The filtrate was then re-filtered through a smaller pre-combusted filter $(\mathrm{GF} / \mathrm{F}$, nominal pore size $0.7 \mu \mathrm{m})$ to retain Synechococcus sp. cells that had not been collected on the first filter. The filters were rinsed with ultra-filtered Indian River water and dried for later analysis by mass spectrometry to determine the amount of ${ }^{15} \mathrm{~N}$ label that was in the raphidophyte cells versus the Synechococcus sp. cells. As this experiment was conducted as a pilot experiment as part of a larger effort (Glibert et al. 2009), these particular treatments were not replicated. All ${ }^{15} \mathrm{~N}$ samples were processed using a Sercon mass spectrometer.

To calculate the ingestion rates of Chattonella subsalsa on Synechococcus sp., the specific N-uptake rate $\left(V\right.$ time $^{-1}$ ) was first calculated using the following equation:

$V=$ atom \% excess/(atom \% enrichment $\times$ time)

in which the atom \% enrichment was that of the initial Synechococcus sp. culture and the atom \% excess was that of the raphidophyte culture (GF/D fraction) after incubation. To correct the atom \% enrichment of the GF/D filters for any contribution by retained Synechococcus sp. cells (or bacteria), the residual amount of Synechococcus sp. on the GF/D filters was determined from the difference of mass of the cells retained on the GF/Fs and the initial culture. The ${ }^{15} \mathrm{~N}$ atom \% enrichment due to the raphidophyte only contribution was then determined:

Atom \% raphidophyte $=[($ measured atom \% GF/D $)$ (mass of raphidophyte + mass of Synechococcus sp.) - (atom \% Synechococcus sp.)

(mass of Synechococcus sp.)]

/ (mass of raphidophyte)

where all units of mass are in $\mu$ mol-N. Grazing rates in terms of amount of $\mathrm{N}$ grazed per time ( $\mathrm{N}$ ingestion rates) were calculated by multiplying the $\mathrm{N}$-specific ingestion rates times the particulate $\mathrm{N}(\mathrm{PN})$ content of the raphidophyte cultures:

$\mathrm{N}$ ingestion rate $=\mathrm{N}$ specific ingestion rate $\times \mathrm{PN}$

Lastly, all ingestion rates were also corrected for the direct uptake of urea by the cultures by subtracting urea uptake rates estimated in parallel experiments as reported in Glibert et al. (2009).

Ingestion rates were also calculated in terms of cells of Synechococcus sp. grazed (cells raphidophyte $\mathrm{e}^{-1} \mathrm{~h}^{-1}$ ) by converting the $\mathrm{N}$ ingestion rate to a cell-specific

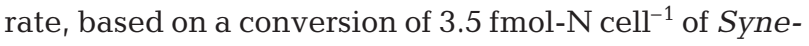
chococcus elongatis (Kana \& Glibert 1987).

Potential grazing impact. We estimated the grazing coefficients (mortality rate due to predation) attributable to Heterosigma akashiwo on Synechococcus spp. by combining field data on the abundances of $H$. akashiwo and Synechococcus spp. with the ingestion 
rates of the predator on Synechococcus sp. obtained in the present study. Data on the abundances of $H$. akashiwo and co-occurring Synechococcus spp. used in this estimation were obtained using the water samples from Masan Bay (in 2004) and Shiwha Bay (2008), Korea. Field data on Chattonella spp. and co-occurring Synechococcus spp. were not available.

The grazing coefficient $\left(g, \mathrm{~d}^{-1}\right)$ was calculated as:

$$
g=C R \times G C \times 24
$$

where $C R\left(\mathrm{ml}\right.$ raphidophyte $\left.{ }^{-1} \mathrm{~h}^{-1}\right)$ is the clearance rate of an raphidophyte predator on Synechococcus sp. prey at a given prey concentration and $G C$ is a grazer concentration (cells ml ${ }^{-1}$ ). $C R$ was calculated as:

$$
C R=I R / p C
$$

where $I R$ (cells eaten raphidophyte $\mathrm{e}^{-1} \mathrm{~h}^{-1}$ ) is the ingestion rate of the algal predator on the target prey and $p c$ (cells ml ${ }^{-1}$ ) is the prey concentration. $C R$ was corrected using $Q_{10}=2.8$ (Hansen et al. 1997) because in situ water temperatures and the temperature used in the laboratory for this experiment $\left(20^{\circ} \mathrm{C}\right)$ were sometimes different.

\section{RESULTS}

\section{Feeding occurrences}

Under TEM, Synechococcus sp. had 2 to 3 distinctive thylakoid layers (Fig. 1A). Unfed Chattonella ovata, Fibrocapsa japonica, and Heterosigma akashiwo had dense chloroplasts near the cell surface (Fig. 1B-D). They also had numerous mucocysts near the surface.

Under TEM and high-resolution video microscopy, Chattonella ovata and Heterosigma akashiwo were observed to feed readily on Synechococcus sp. (see Figs. 2 to 6). Under TEM, various numbers of Synechococcus sp., ranging from 1 to 100s, were observed in food vacuoles inside the protoplasm of C. ovata (Fig. 2). When C. ovata cells with 1 or 2 single ingested Synechococcus sp. cells were examined, the Synechococcus sp. cells were observed inside food vacuoles in mucocysts of $C$. ovata. This implies that $C$. ovata engulfed the single prey cell through its mucocysts. The sizes of the mucocysts were 1.6 to $3.7 \mu \mathrm{m}$ long by 1.5 to $3.0 \mu \mathrm{m}$ wide $(\mathrm{n}=15)$. The size of the mucocyst openings of C. ovata was ca. 2 to $3 \mu \mathrm{m}$. A large food vacuole containing 100s of Synechococcus sp. cells was observed in the center of C. ovata. Small food vacuoles containing 1 or several Synechococcus sp. cells may have merged to form a larger package (Fig. 2).

Under TEM, Heterosigma akashiwo also had food vacuoles containing various numbers of Synechococcus sp. (Fig. 3). When ca. 160 transversal TEM serial sections (70 nm layer serial sections, i.e. ca. $11 \mu \mathrm{m})$ from the top to the bottom of $1 \mathrm{H}$. akashiwo cell were examined, 20 to 30 mucocysts and 15 to 20 chloroplasts were observed. The mucocysts were scattered in the cell body of $H$. akashiwo and some of them contained prey cells. The mucocysts look like sacks 0.7 to $2.1 \mu \mathrm{m}$ long by 1.2 to $2.1 \mu \mathrm{m}$ wide by 0.6 to $2.5 \mu \mathrm{m}$ thick ( $\mathrm{n}=$ $20)$. The size of the mucocyst openings was ca. $2 \mu \mathrm{m}$. The mucocyst size seemed to limit the upper limit of the prey size that the raphidophyte was able to feed on. No prey cells were observed inside the funnelshaped groove from which 2 flagella arose.

Under TEM, no Synechococcus sp. cells were observed inside the protoplasm of Fibrocapsa japonica cells (n > 100; Fig. 4). However, very rarely (<1\%) 1 to 2 Synechococcus sp. cells (bright orange-colored inclusions) were observed in the protoplasms of $F$. japonica cells under an epifluorescence microscope (Fig. 4). In conclusion, all 3 raphidophytes are able to feed on Synechococcus sp., but the frequency of ingestion of Synechococcus sp. by F. japonica was very low.

\section{Feeding behavior}

On high-resolution video microscopy, Chattonella ovata (and Heterosigma akashiwo) displayed 2 undulating flagella, but did not generate detectable feeding currents. C. ovata (and H. akashiwo) excreted mucus from several mucocysts along the cell body. As $C$. ovata (and $H$. akashiwo) swam in rotation, up to 12 Synechococcus sp. cells (and up to 4 cells) were observed to attach to the mucus excreted from many mucocysts along the cell body (Fig. 5). C. ovata engulfed a single Synechococcus sp. cell through a mucocyst within 7 to $20 \mathrm{~s}$ after the prey initially attached to the mucus (Fig. 6A-F and video available at www.int-res.com/articles/suppl/a058p181_app/), while $H$. akashiwo engulfed a single Synechococcus sp. cell within 40 to $75 \mathrm{~s}$ (Fig. 6G-L).

\section{Effects of prey concentration}

The mean prey concentrations in the experiment on the feeding by Chattonella ovata on Synechococcus sp. were $4.4 \times 10^{3}$ to $3.2 \times 10^{6}$ cells $\mathrm{ml}^{-1}$. With increasing prey concentration, the ingestion rate of C. ovata on Synechococcus sp. continuously increased (Fig. 7). At a given prey concentration, the highest ingestion rate of C. ovata on Synechococcus sp. was 18.6 cells raphidophyte $^{-1} \mathrm{~h}^{-1}$. The maximum clearance rate of C. ovata on Synechococcus sp. was $0.1 \mu$ raphidophyte ${ }^{-1} \mathrm{~h}^{-1}$.

The initial prey concentrations in the experiment on the feeding by Chattonella subsalsa on Synechococcus 


\section{A}
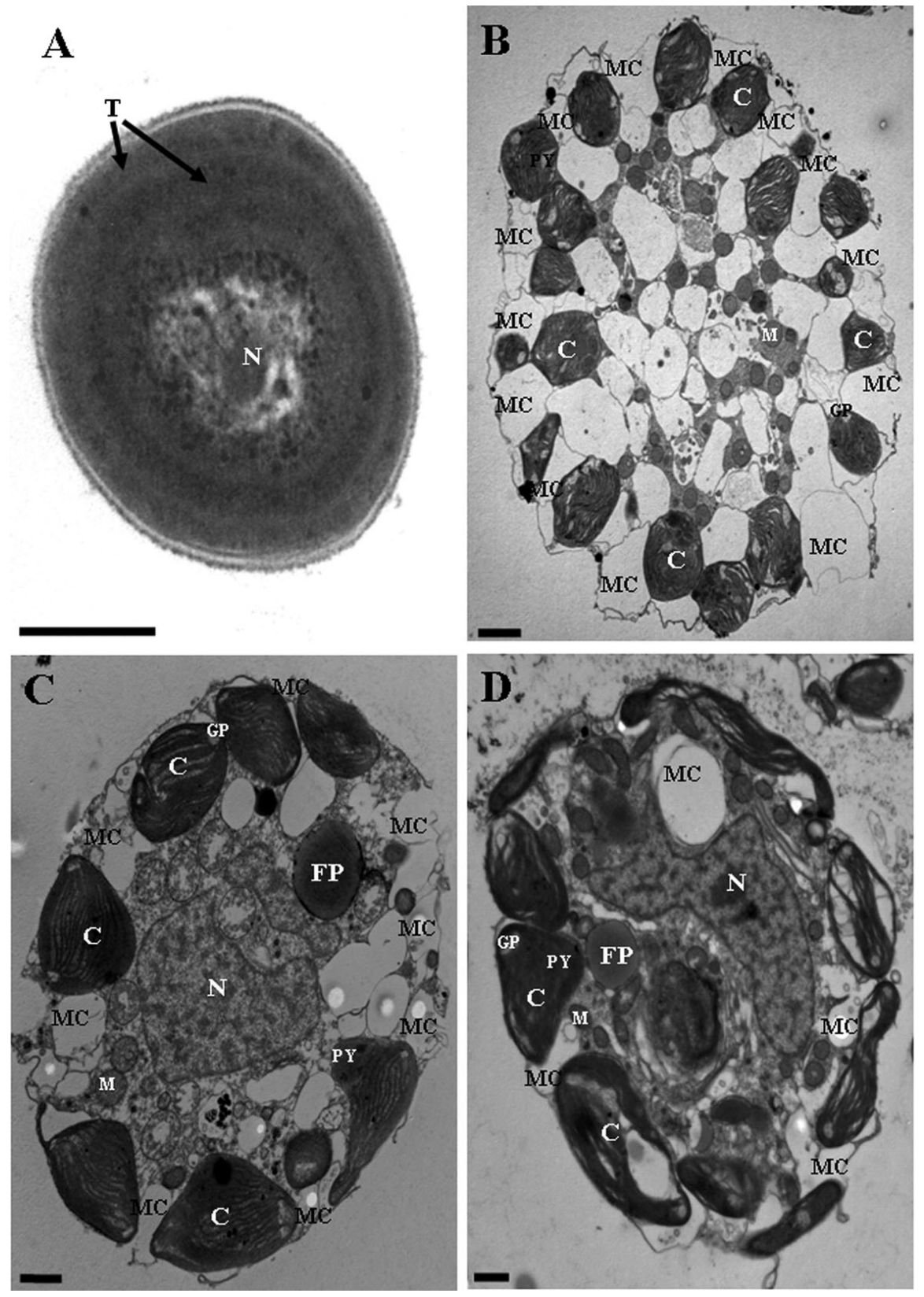

Fig. 1. Transmission electron micrographs of the cyanobacterium and raphidophytes growing photosynthetically. (A) Synechococcus sp. with 2 distinct layers of thylakoid (T). Unfed (B) Chattonella ovata, (C) Heterosigma akashiwo, and (D) Fibrocapsa japonica. C: chloroplast, FP: fatty particle, GP: genophore, M: mitochondrion, MC: mucocyst, N: nucleus, PY: pyrenoid. Scale bars = $0.2 \mu \mathrm{m}$ for (A), $2 \mu \mathrm{m}$ for (B), and $1 \mu \mathrm{m}$ for $(\mathrm{C}, \mathrm{D})$

sp. were $1.1 \times 10^{5}$ to $5.5 \times 10^{6}$ cells $\mathrm{ml}^{-1}$. With increasing prey concentration, the ingestion rate of C. subsalsa on Synechococcus sp. continuously increased (Fig. 7). At the given prey concentration, the highest ingestion rate of C. subsalsa on Synechococcus sp. was 20.5 cells raphidophyte ${ }^{-1} \mathrm{~h}^{-1}$.

The initial concentrations of Synechococcus sp. in the experiment on the feeding by Heterosigma akashiwo on Synechococcus sp. were $6.4 \times 10^{3}$ to $4.6 \times$ $10^{6}$ cells $\mathrm{ml}^{-1}$. With increasing prey concentration, the ingestion rate of $H$. akashiwo on Synechococcus sp. continuously increased (Fig. 8). At the given prey concentration, the highest ingestion rate of $H$. akashiwo on Synechococcus sp. was 3.9 cells raphidophyte $\mathrm{e}^{-1} \mathrm{~h}^{-1}$. The maximum clearance rate of $H$. akashiwo on Synechococcus sp. was $0.3 \mu \mathrm{l}$ raphidophyte $\mathrm{h}^{-1} \mathrm{~h}^{-1}$. 

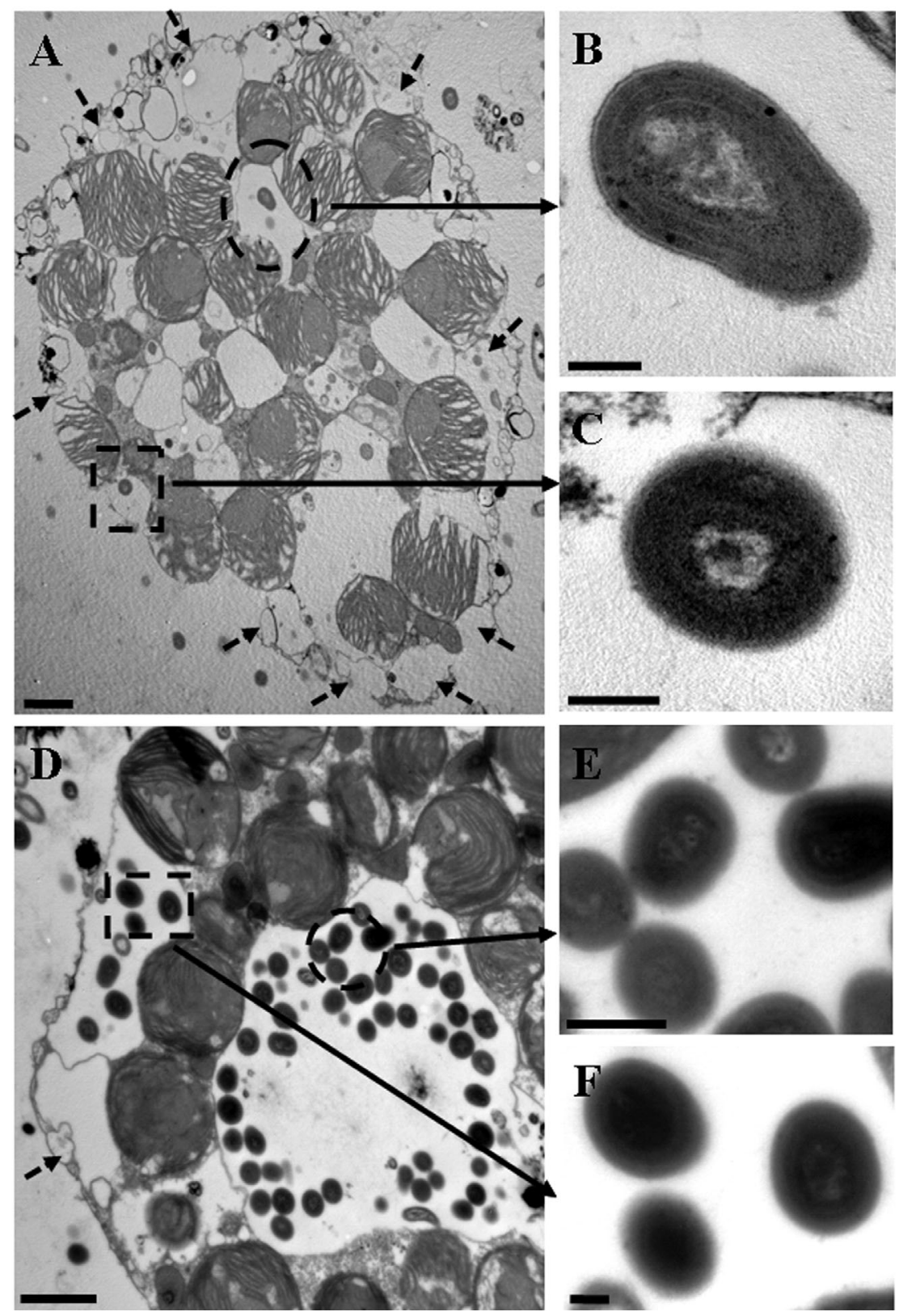

Fig. 2. Transmission electron micrographs of Chattonella ovata fed single Synechococcus sp. cells. (A) C. ovata cell with 2 single Synechococcus sp. cells (inside the dashed circle and square). (B,C) Enlarged from (A): single Synechococcus sp. cells inside food vacuoles. (D) C. ovata cell with a relatively small food vacuole containing 6 single Synechococcus sp. cells (3 inside the dashed square) and a large food vacuole containing tens of single Synechococcus sp. cells (5 inside the dashed circle). (E,F) Enlarged from (D): single Synechococcus sp. cells inside food vacuoles. Dashed arrows indicate mucocysts. Scale bars $=2 \mu \mathrm{m}$ for $(\mathrm{A}, \mathrm{D})$, $0.2 \mu \mathrm{m}$ for $(\mathrm{B}, \mathrm{C}, \mathrm{E})$, and $0.5 \mu \mathrm{m}$ for $(\mathrm{F})$

\section{Grazing impact}

The grazing coefficients attributable to Heterosigma akashiwo on co-occurring Synechococcus spp. in Masan Bay and Shiwha Bay $(\mathrm{n}=23)$ were 0.001 to $1.238 \mathrm{~d}^{-1}$ when the abundances of $H$. akashiwo and Synechococcus spp. were 22 to 228000 cells ml$^{-1}$ and 51 to 194460 cells ml$^{-1}$, respectively (Fig. 9).

\section{DISCUSSION}

\section{Raphidophyte predators of Synechococcus sp. and their feeding behavior}

This is the first report on feeding by raphidophytes on cyanobacteria. All 4 raphidophytes tested in the present study were able to feed on Synechococcus sp., 


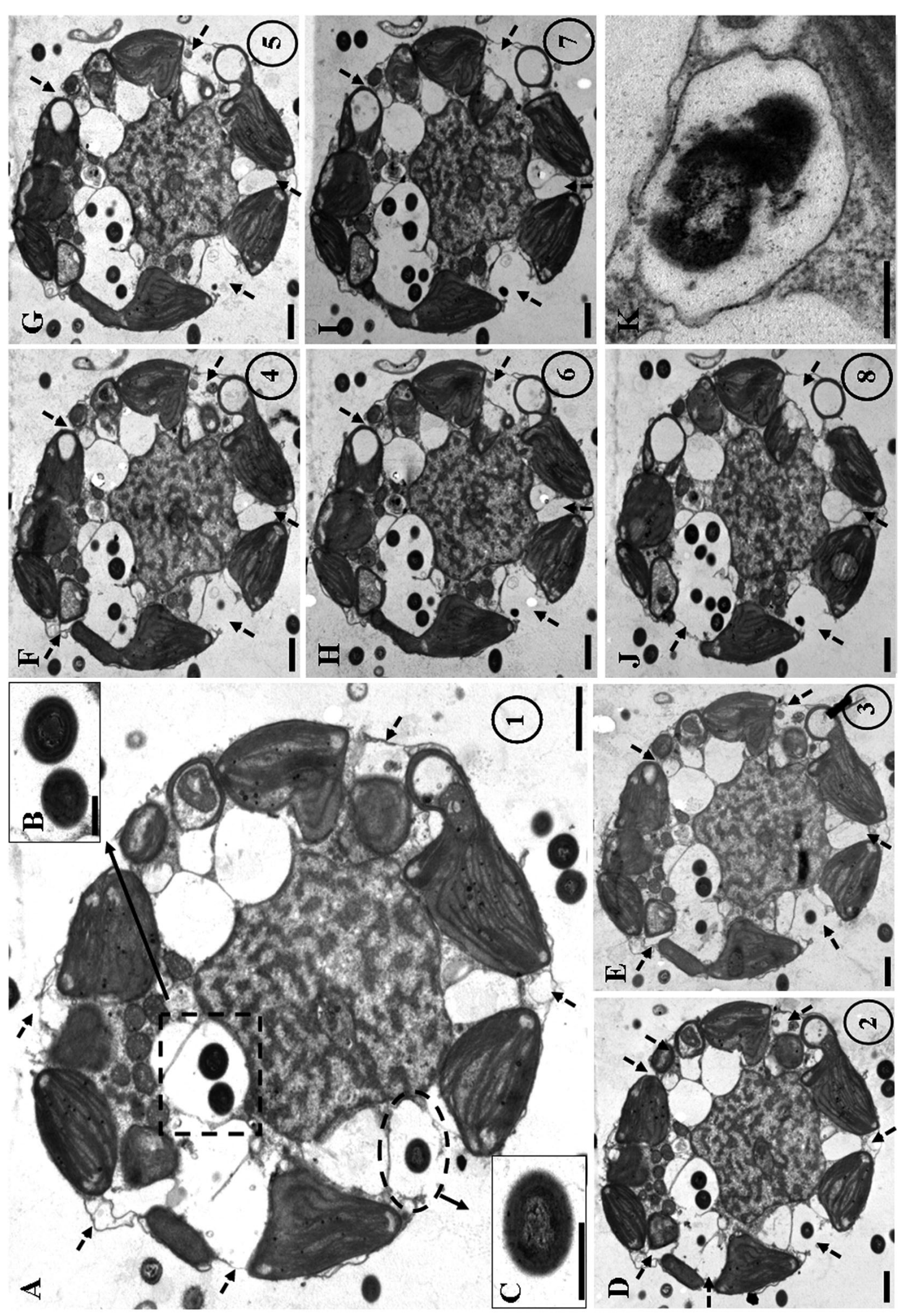

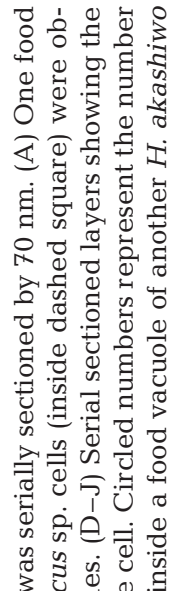

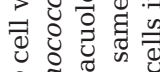

구ㅇㅝㅛ

ส $5: 0$

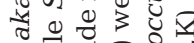

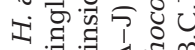

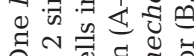

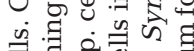

व

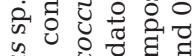

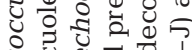

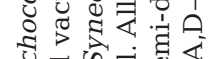

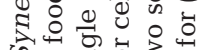

월 责

के

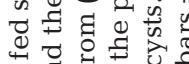

完范

चु

శี

菏 0.

जी 0

牙 0 .

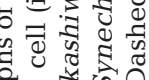

वे क्षे

ป 중

द 0 ०

ㄷㅇㅇㅎㅕ

\section{ब 웡}

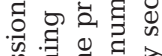

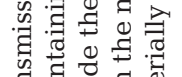

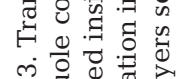



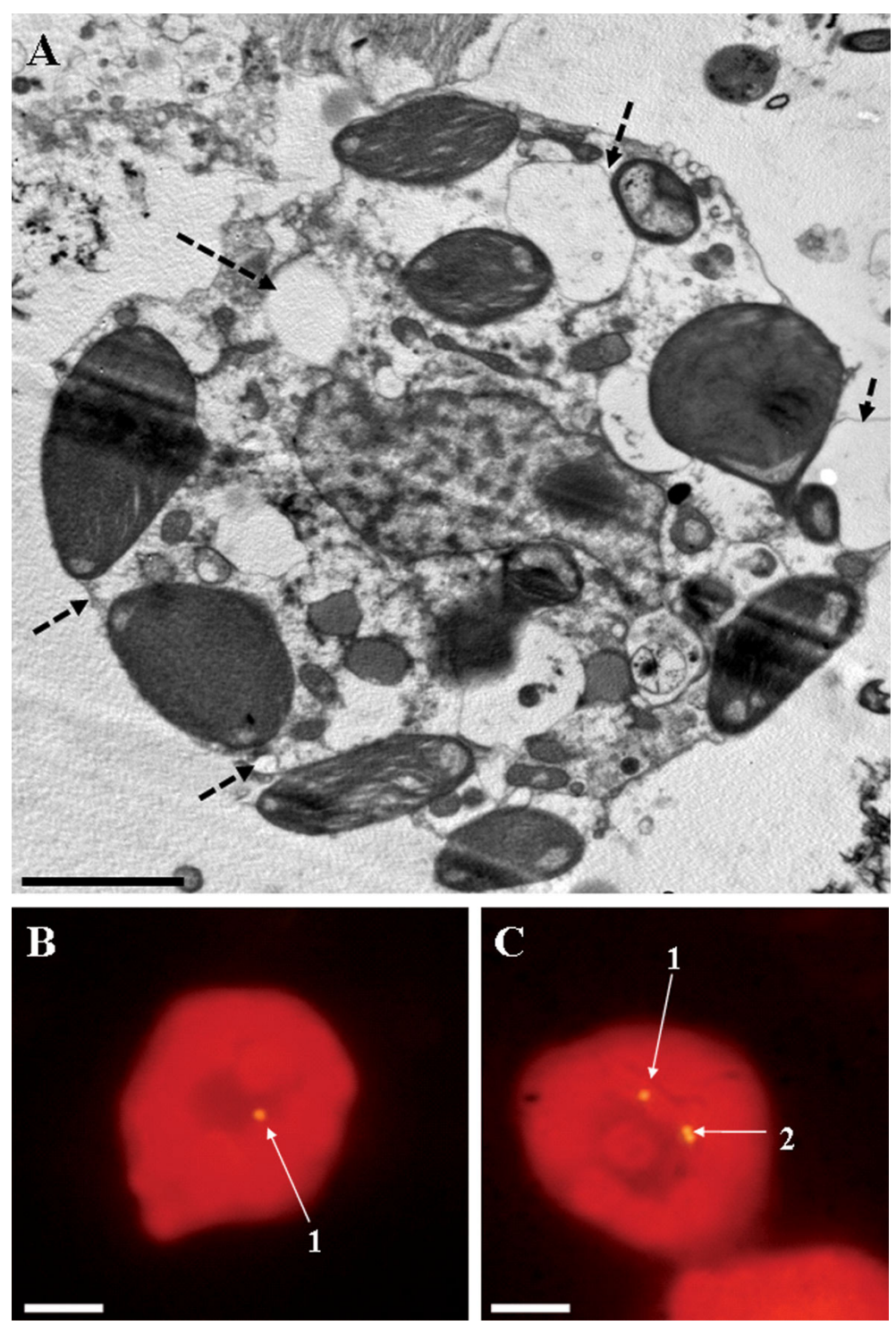

Fig. 4. Fibrocapsa japonica observed under (A) transmission electron microscopy and $(\mathrm{B}, \mathrm{C})$ epifluorescence microscopy after incubation with live Synechococcus sp. cells. (A) No Synechococcus sp. cell was observed inside the protoplasm of the predator; dashed arrows indicate mucocysts. F. japonica cells containing (B) 1 and (C) 2 Synechococcus sp. cells (colored orange). Scale bars $=2 \mu \mathrm{m}$

but ingestion of Synechococcus sp. by Fibrocapsa japonica was very rare. The size of F. japonica is between that of Chattonella ovata and Heterosigma akashiwo. Therefore, the predator sizes may not be the cause of the lack in feeding. On the phylogeny tree based on small subunit ribosomal RNA of the Raphidophyceae, F. japonica is an ancestor of Chattonella spp. and Heterosigma spp. (Bowers et al. 2006). F. japonica may have fewer enzymes involved in prey recognition and/or digestion of Synechococcus sp. compared to Chattonella spp. and H. akashiwo. It would be worthwhile to investigate the genomes and proteomes of these 3 raphidophytes. In natural environments, Chattonella spp. may compete with $H$. akashiwo for Synechococcus spp. prey, but not with F. japonica.

In our preliminary experiments, Chattonella ovata and Heterosigma akashiwo fed very well on heterotrophic bacteria, Synechococcus sp. and beads $\leq 2 \mu \mathrm{m}$, but they did not feed on Isochrysis galbana (ca. $5 \mu \mathrm{m}$ ESD) and an unidentified cryptophyte $(5.6 \mu \mathrm{m})$, diverse mixotrophic dinoflagellates $(\geq 6 \mu \mathrm{m})$, and beads sized 3 to $12 \mu \mathrm{m}$. Therefore, the upper prey size limit for both $C$. ovata and $H$. akashiwo seems to be ca. $2 \mu \mathrm{m}$. Based on the TEM serial sectioning, the size of the mucocyst openings of C. ovata is ca. $3 \mu \mathrm{m}$, while that of $H$. akashiwo is ca. $2 \mu \mathrm{m}$. Thus, the size of the mucocysts of these raphidophytes may be a critical factor affecting the upper size limit of edible prey. Meanwhile, many mixotrophic dinoflagellates have been reported to feed on I. galbana, cryptophytes, diverse mixotrophic dinoflagellates, and/or heterotrophic protists (Stoecker 1999, Jeong et al. 2005b, Burkholder et al. 2008). The mixotrophic dinoflagellates feed on prey cells by peduncles (Hansen \& Calado 1999, Berge et al. 2008) or engulfment (Skovgaard 1996, Jeong et al. 2004). In engulfment feeding, they engulf a prey cell through the sulcus, apical horn, or body suture (Jeong et al. 2005b,c). These diverse feeding behaviors and larger feeding openings enable the mixotrophic dinoflagellates to feed on diverse prey, ranging from heterotrophic bacteria to much larger heterotrophic prey. Therefore, in terms of prey items and feeding behaviors, the raphidophytes may be less-flexible red-tide organisms compared to mixotrophic dinoflagellates.

Heterosigma akashiwo is known to be present in 3 major locations where nutrient concentrations are low (Taylor et al. 1994) or high (Han et al. 1989), and in an upwelling area (Tilstone et al. 1994). Taylor et al. (1994) reported that the abundance of $H$. akashiwo had negative correlations with the concentrations of nitrate and phosphate. Thus, in the waters where the nutrient concentrations are low, H. akashiwo may maintain its populations by taking up dissolved organic materials and/or feeding on heterotrophic bacteria and Synechococcus sp. 

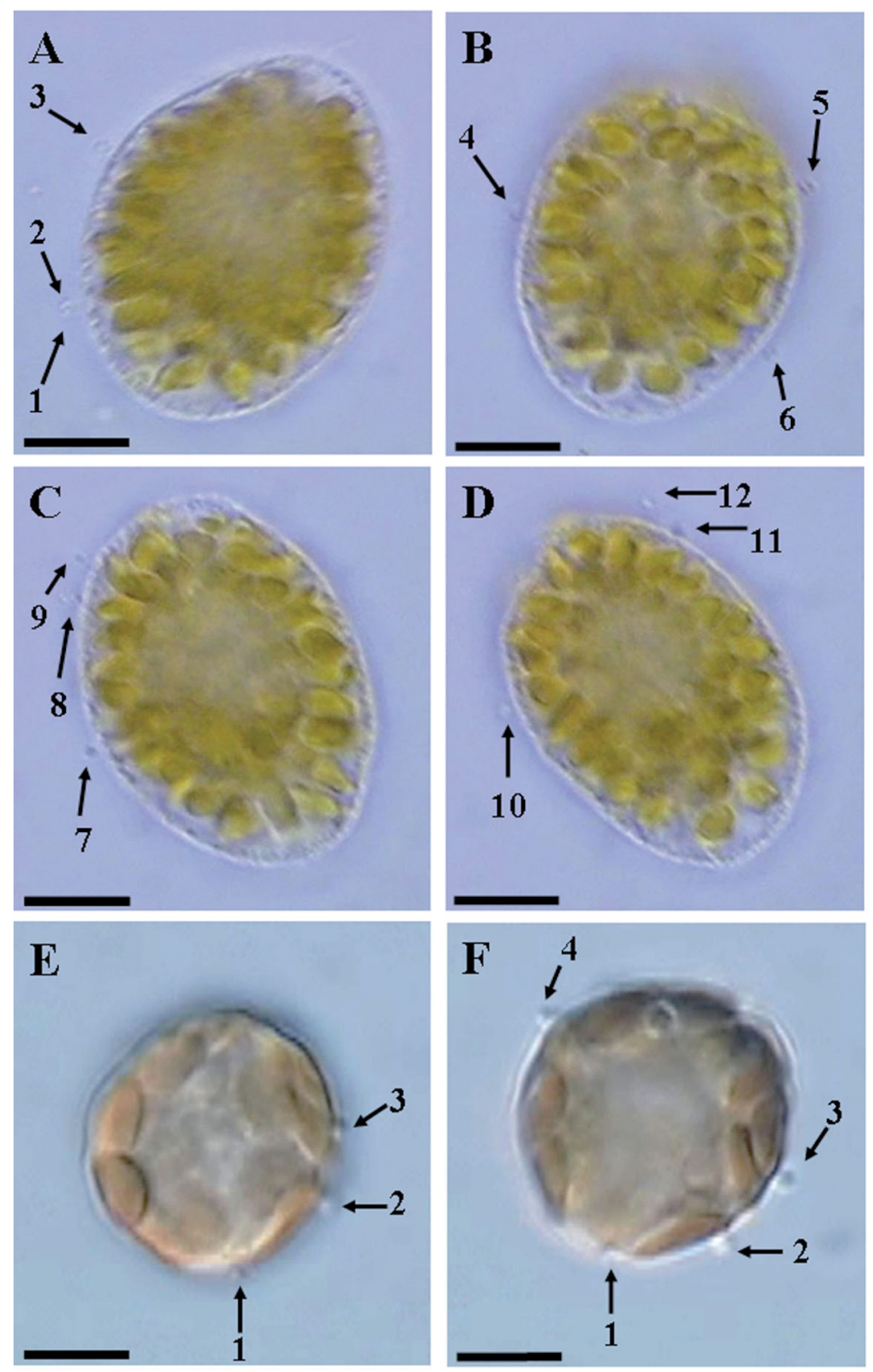

Fig. 5. (A-D) Twelve living Synechococcus sp. cells (arrows) captured by the mucus excreted from mucocysts along the cell body of a Chattonella ovata cell. As the C. ovata cell rotated, all Synechococcus sp. cells attached to the cell body of the predator cell were counted. All predator cells in (A-D) were the same cell. Scale bars $=10 \mu \mathrm{m}$. (E,F) Four living Synechococcus sp. cells (arrows) captured by the mucus excreted from mucocysts along the cell body of Heterosigma akashiwo. Both predator cells in $(E, F)$ were the same cell. Scale bar $=5 \mu \mathrm{m}$. All images were observed with epifluorescence microscopy and recorded using highresolution video microscopy

The feeding behavior of the raphidophytes, which engulfed Synechococcus sp. cells captured in mucus excreted by their mucocysts, is somewhat different from most heterotrophic nanoflagellates or the heterotrophic dinoflagellates Oxyrrhis marina and Gyrodinium spp.; these intercept and then ingest a single heterotrophic bacterial cell in feeding currents generally generated by the flagella of the predators (Boenigk \& Arndt 2000, Jeong et al. 2008). Cells of Heterosigma akashiwo and Chattonella spp. have been reported to be enveloped by glycocalyx (Edvardsen \& Imai 2006). Before the present study, the function of the mucus cover had been unclear, but it was suggested to have an affinity to iron (Honjo 1993). The mucus was also suggested to cause fish death (Bourdelais et al. 2002). The results of the present study clearly show that one of the roles of the mucus is to capture small prey. In geological scales, fish appeared ca. 390 million years ago (Shubin et al. 2006). Cyanobacteria and heterotrophic bacteria appeared much earlier than fish. Thus, mucus may have originally developed to capture bacteria, and fish suffocation due to the mucus may be a side effect. Also, a function of the mucocysts of the raphidophytes had been thought to be just excreting mucus (Hallegraeff \& Hara 1995). The present study reveals that the mucocysts are used as the location where the raphidophytes engulf prey cells.

\section{Ingestion rates and grazing impact}

The highest ingestion rate of Chattonella ovata or C. subsalsa on Synechococcus sp. under the conditions provided in the present study (ca. 18.6 to 20.5 cells grazer ${ }^{-1} \mathrm{~h}^{-1}$ ) is comparable to that of the mixotrophic dinoflagellates Gymnodinium impudicum and Gonyaulax spinifera on the same prey (ca. 15 to 24 cells grazer ${ }^{-1} \mathrm{~h}^{-1}$ ), while the highest ingestion rate of Heterosigma akashiwo on Synechococcus sp. (ca. 3.9 cells grazer ${ }^{-1} \mathrm{~h}^{-1}$ ) is also similar to that of the mixotrophic dinoflagellates Alexandrium minutum and Heterocapsa triquetra (ca. 3 to 4 cells grazer ${ }^{-1} \mathrm{~h}^{-1}$ ). Therefore, C. ovata and C. subsalsa may compete with Gymnodinium impudicum and Gonyaulax spinifera for Synechococcus sp. prey if they co-occur and the prey concentration limits growth of these predators, while Heterosigma akashiwo may do the same with A. minutum and Heterocapsa triquetra.

The highest ingestion rate of Chattonella ovata or $C$. subsalsa on Synechococcus sp. under the conditions provided in the present study was higher than the maximum ingestion rates of the small heterotrophic nanoflagellates Picophagus flagellatus, Pseudobodo sp., Cafeteria roenbergensis, and Bodo saltans on 
Fig. 6. Feeding processes of raphidophyte on a living Synechococcus sp. cell observed with epifluorescence microscopy, recorded using high-resolution video microscopy. Serial photos showed the ingestion of the single Synechococcus sp. cell (arrow) by the raphidophyte at the cell surface near a mucocyst. (A-F) A single Synechococcus sp. cell captured by a Chattonella ovata cell; a video is also available at www.intres.com/articles/suppl/a058p181_app/. $(\mathrm{B}, \mathrm{C})$ Half or more of the Synechococcus sp. cell was engulfed by C. ovata. (D) Synechococcus sp. cell was completely engulfed by $C$. ovata. (E,F) Enlarged from (A) and (D), respectively. (G-L) Feeding processes of Heterosigma akashiwo on a living Synechococcus sp. cell. Serial photos showed the ingestion of the single Synechococcus sp. cell (arrow) by the raphidophyte at the cell surface near a mucocyst. All raphidophyte cells were the same cell. Scale bars = $10 \mu \mathrm{m}$ for $(\mathrm{A}-\mathrm{D}), 2 \mu \mathrm{m}$ for $(\mathrm{E}, \mathrm{F})$, and $5 \mu \mathrm{m}$ for $(\mathrm{G}-\mathrm{K})$
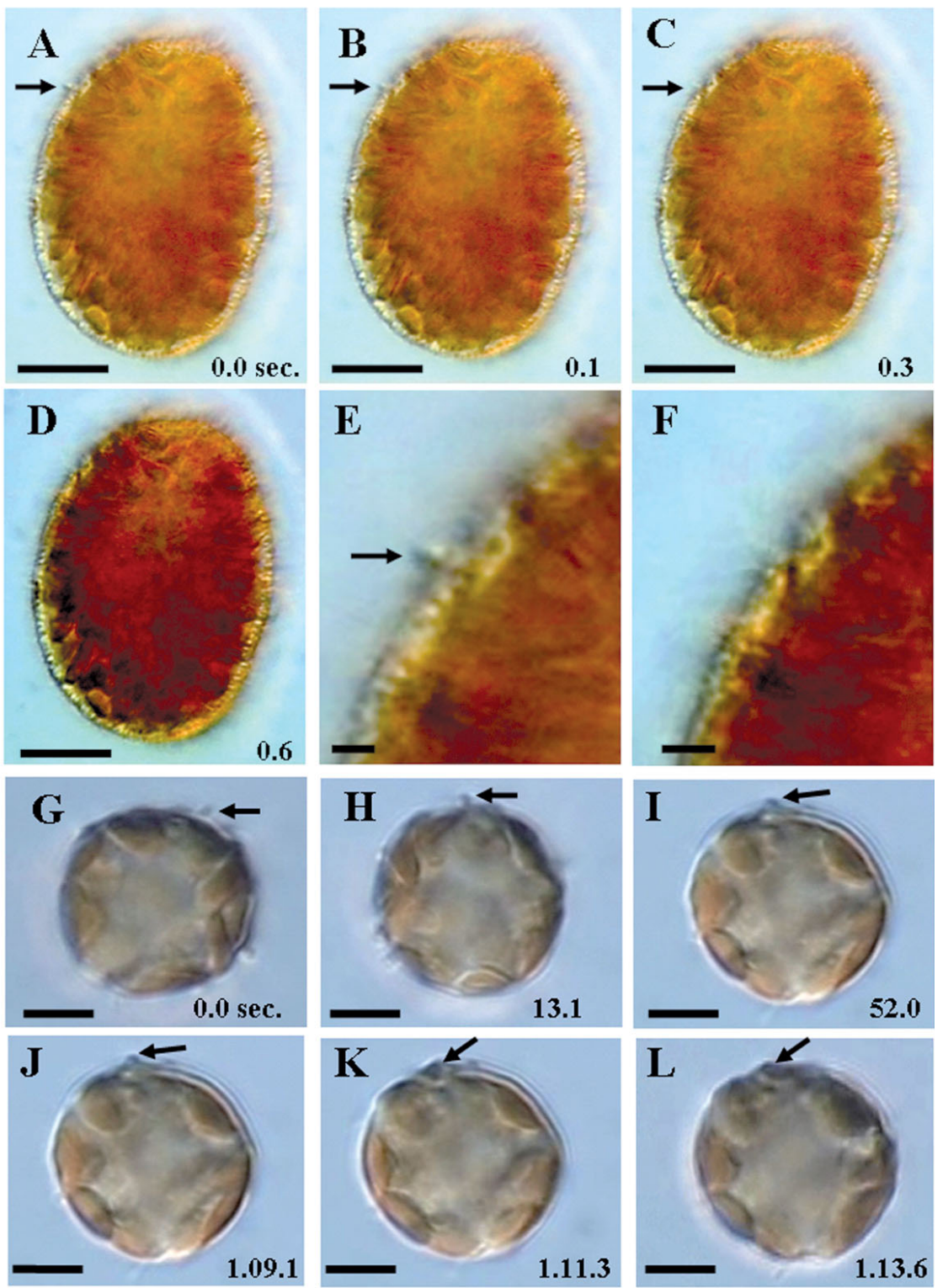

Synechococcus sp. (Dolan \& Simek 1998, Boenigk et al. 2001, Guillou et al. 2001, Christaki et al. 2002) and comparable to that of the ciliate Uronema sp. (Christaki et al. 1999), when corrected to $20^{\circ} \mathrm{C}$ using $Q_{10}=2.8$ (Hansen et al. 1997). However, the highest ingestion rate of Heterosigma akashiwo on Synechococcus sp. under the conditions provided in the present study is between the maximum ingestion rates of Pseudobodo sp. and Cafeteria roenbergensis. Therefore, Chattonella ovata, Chattonella subsalsa, and H. akashiwo may sometimes compete with the heterotrophic nanoflagellates and ciliates for Synechococcus sp. as well if they co-occur.

The actual initial concentrations of heterotrophic bacteria in the Chattonella ovata and Heterosigma akashiwo feeding experiments were $<13 \%$ and $<18 \%$ of Synechococcus sp., respectively. The presence of these heterotrophic bacteria may have somewhat lowered the ingestion rates of $C$. ovata and $H$. akashiwo on Synechococcus sp. Also, different strains of these raphidophytes may have somewhat different rates and thus it would be worthwhile to measure ingestion rates of different strains of the raphidophytes.

Interestingly, Chattonella ovata and Heterosigma akashiwo had much lower maximum clearance rates than the heterotrophic nanoflagellates and ciliates. Capturing and engulfing prey cells using mucus excreted from the mucocysts (C. ovata and $H$. akashiwo) may be a less efficient feeding mechanism than intercepting prey cells in feeding currents or filter 


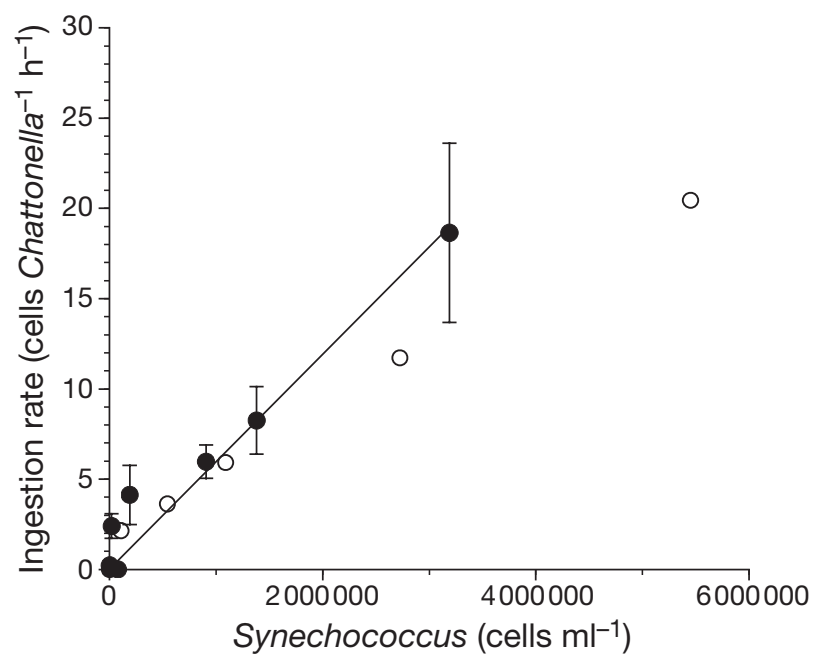

Fig. 7. Ingestion rate (IR) of Chattonella ovata $(\bullet)$ and C. subsalsa (O) on Synechococcus sp. as a function of initial prey concentration $(p c)$. Data are mean $\pm \mathrm{SE}$ for $C$. ovata $(\mathrm{n}=3$ for each prey concentration) and single treatments for $C$. subsalsa ( $\mathrm{n}=1$ for each prey concentration). The curve was fitted by a linear equation using all treatments in Expt 3 (for $C$. ovata): $I R=5.66 \times 10^{-6} \times p c, \mathrm{r}^{2}=0.668$

feeding (the heterotrophic nanoflagellates and ciliates). As described in 'Feeding behaviour', C. ovata and $H$. akashiwo do not generate detectable feeding currents similar to those created by the heterotrophic nanoflagellates and ciliates (Fenchel 1987, Boenigk \& Arndt 2000). The heterotrophic nanoflagellates and ciliates may draw feeding currents and then capture prey cells carried inside the feeding currents. Thus,

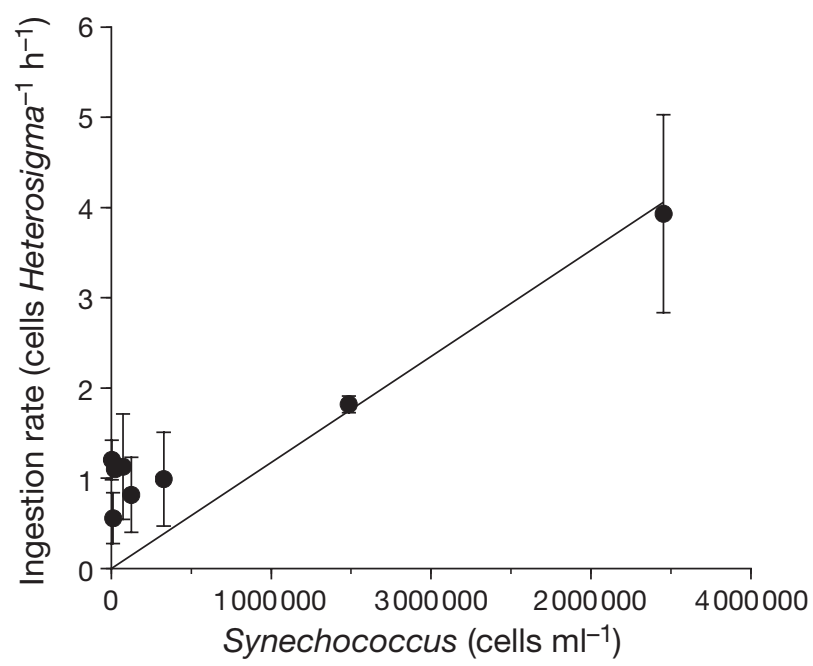

Fig. 8. Ingestion rate (IR) of Heterosigma akashiwo on Synechococcus sp. as a function of initial prey concentration $(p c)$. Data are mean $\pm \mathrm{SE}$. The curve was fitted by a linear equation using all treatments in the experiment: $I R=1.18 \times 10^{-6} \times p c$,

$$
r^{2}=0.508
$$

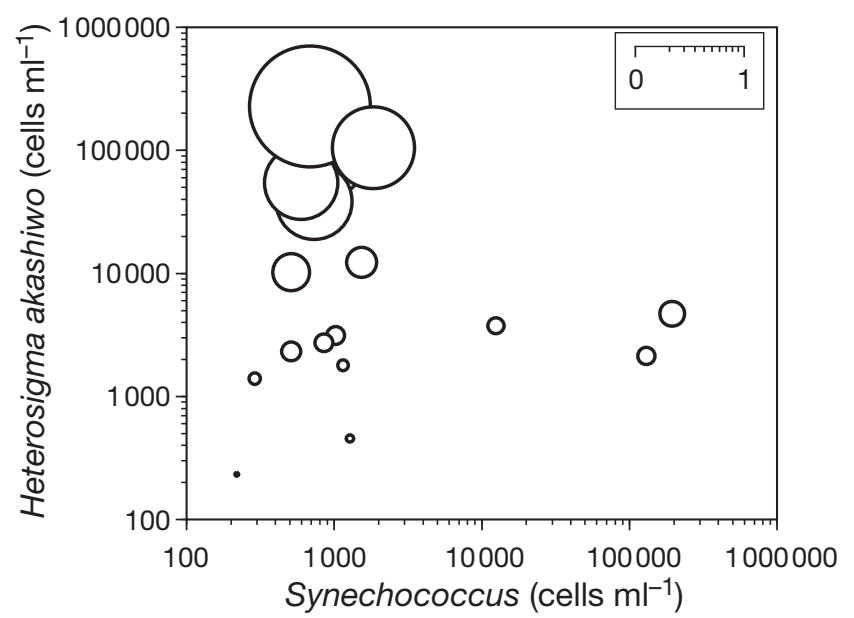

Fig. 9. Calculated grazing coefficients ( $g$ ) of Heterosigma akashiwo $(\mathrm{n}=23)$ in relation to the concentration of co-occurring Synechococcus sp. (see Eqs. 4 \& 5). Clearance rates, measured under the conditions provided in the present study, were corrected using $Q_{10}=2.8$ (Hansen et al. 1997) because in situ water temperatures and the temperature used in the laboratory for this experiment $\left(20^{\circ} \mathrm{C}\right)$ were sometimes different.

The scales of the circles in the inset boxes are $g\left(\mathrm{~d}^{-1}\right)$

they have relatively high clearance rates. However, $C$. ovata and $H$. akashiwo may need to swim through Synechococcus sp. cells to capture prey cells without filtering, which may be responsible for their relatively lower maximum clearance rates.

The grazing coefficients attributable to Heterosigma akashiwo on co-occurring Synechococcus spp. in Masan Bay and Shiwha Bay were 0.001 to $1.238 \mathrm{~d}^{-1}$ (i.e. up to $71 \%$ of a Synechococcus spp. population was removed by a population of $H$. akashiwo in $1 \mathrm{~d}$ ) when the abundances of $H$. akashiwo and Synechococcus sp. were 22 to 87680 and 51 to 194460 cells ml$^{-1}$, respectively. Therefore, $H$. akashiwo may sometimes have a considerable grazing impact on populations of co-occurring Synechococcus spp. in Masan and Shiwha Bays.

The results of the present study are ecologically important to planktonic communities for the following reasons: (1) in the marine planktonic food webs, some raphidophytes are able to feed on one of the most abundant photosynthetic microorganisms in the world's oceans (Ferris \& Palenik 1998, Li 1998). Also, Heterosigma akashiwo may sometimes have a considerable grazing impact on populations of co-occurring Synechococcus sp.; thus, we should take raphidophytes into consideration as important predators on Synechococcus sp. (2) Chattonella ovata, C. subsalsa, and $H$. akashiwo feed well on Synechococcus sp., but Fibrocapsa japonica rarely does. Thus, the roles of $C$. ovata, C. subsalsa, and H. akashiwo may be different from $F$. japonica in planktonic food webs and bloom dynamics. 
Acknowledgements. We thank J. S. Kim and J. Y. Song for technical support. This paper was funded by grants from the Korean Research Foundation (2007-070-C00789), KOSEF (R01-2008-000-10468-0), and KIMST award to H.J.J. and from NOAA Grant NO06NOS4780075 award to P.M.G. and D.J. This is contribution number 4308 from the University of Maryland Center for Environmental Science.

\section{LITERATURE CITED}

Agawin NSR, Duarte CM, Agusti S, Vaque D (2004) Effect of $\mathrm{N}: \mathrm{P}$ ratios on response of Mediterranean picophytoplankton to experimental nutrient inputs. Aquat Microb Ecol 34:57-67

Berge T, Hansen PJ, Moestrup O (2008) Feeding mechanism, prey specificity and growth in light and dark of the plastidic dinoflagellate Karlodinium armiger. Aquat Microb Ecol 50:279-288

Boenigk J, Arndt H (2000) Comparative studies on the feeding behavior of two heterotrophic nanoflagellates: the filter-feeding choanoflagellate Monosiga ovata and the raptorial-feeding kinetoplastid Rhynchomonas nasuta. Aquat Microb Ecol 22:243-249

Boenigk J, Matz C, Juergens K, Arndt H (2001) The influence of preculture conditions and food quality on the ingestion and digestion process of three species of heterotrophic nanoflagellates. Microb Ecol 42:168-176

Bourdelais AJ, Tomas CR, Naar J, Kubanek J, Baden DG (2002) New fish-killing alga in coastal Delaware produces neurotoxins. Environ Health Perspect 110:465-470

Bowers HA, Tomas CR, Tengs T, Kempton JW, Lewitus AJ, Oldach DW (2006) Raphidophyceae (Chadefaud ex Silva) systematics and rapid identification: sequence analyses and realtime PCR assays. J Phycol 42:1333-1348

Burkholder JM, Glibert PM, Skelton HM (2008) Mixotrophy, a major mode of nutrition for harmful algal species in eutrohic waters. Harmful Algae 8:77-93

Christaki U, Jacquet S, Dolan JR, Vaulot D, Rassoulzadegan F (1999) Growth and grazing on Prochlorococcus and Synechococcus by two marine ciliates. Limnol Oceanogr 144: $52-61$

> Christaki U, Courties C, Karayanni H, Giannakourou A, Maravelias C, Kormas KA, Lebaron P (2002) Dynamic characteristics of Prochlorococcus and Synechococcus consumption by bacterivorous nanoflagellates. Microb Ecol 43:341-352

> Clough J, Strom S (2005) Effects of Heterosigma akashiwo (Raphidophyceae) on protist grazers: laboratory experiments with ciliates and heterotrophic dinoflagellates. Aquat Microb Ecol 39:121-134

Demir E, Coyne KJ, Doblin MA, Handy SM, Hutchins DA (2008) Assessment of microzooplankton grazing on Heterosigma akashiwo using a species-specific approach combining quantitative real-time PCR (QPCR) and dilution methods. Microb Ecol 55:583-594

Dolan JR, Simek K (1998) Ingestion and digestion of an autotrophic picoplankter, Synechococcus, by a heterotrophic nanoflagellate, Bodo saltans. Limnol Oceanogr 43: 1740-1746

Edvardsen B, Imai I (2006) The ecology of harmful prymnesiophytes and raphidophytes. In: Granéli E, Turner JT (eds) The ecology of harmful algae. Springer, Berlin, p 67-80

Fenchel T (1987) Ecology of protozoa: the biology of free living phagotrophic protists. Springer-Verlag, New York

> Ferris MJ, Palenik B (1998) Niche adaptation in ocean cyanobacteria. Nature 396:226-228
Frost BW (1972) Effects of size and concentration of food particles on the feeding behavior of the marine planktonic copepod Calanus pacificus. Limnol Oceanogr 17:805-815

Glibert PM, Heil CA, Hollander D, Revilla M, Hoare A, Alexander J, Murasko S (2004) Evidence for dissolved organic nitrogen and phosphorus uptake during a cyanobacterial bloom in Florida Bay. Mar Ecol Prog Ser 280: 73-83

Glibert PM, Burkholder JM, Kana TM, Alexander J, Skelton $\mathrm{H}$, Shilling C (2009) Grazing by Karenia brevis on Synechococcus enhances its growth rate and may help to sustain blooms. Aquat Microb Ecol 55:17-30

Guillard RRL, Ryther JH (1962) Studies of marine planktonic diatoms. I. Cyclotella nana Hustedt and Detonula confervacea (Cleve) Grun. Can J Microbiol 8:229-239

Guillou L, Jacquet S, Chretiennot-Dinet MJ, Vaulot D (2001) Grazing impact of two small heterotrophic flagellates on Prochlorococcus and Synechococcus. Aquat Microb Ecol 26:201-207

Hallegraeff GM, Hara Y (1995) Taxonomy of harmful marine raphidophytes. In: Hallegraeff, GM, Anderson DM, Cembella AD (eds) Manual on harmful marine microalgae. UNESCO, Paris, p 365-371

Han MS, Furuya K, Nemoto T (1989) Species specific photosynthesis of red tide phytoplankton in Tokyo Bay. In: Okaichi T, Anderson DM, Nemoto T (eds) Red tides: biology, environmental science and toxicology. Elsevier, Amsterdam, p 213-216

> Hansen PJ, Calado AJ (1999) Phagotrophic mechanisms and prey selection in free-living dinoflagellates. J Eukaryot Microbiol 46:382-389

Hansen PJ, Bjornsen PK, Hansen BW (1997) Zooplankton grazing and growth: scaling within the 2-2,000-um body size range. Limnol Oceanogr 42:687-704

Hara Y, Chihara M (1987) Morphology, ultrastructure and taxonomy of the raphidophycean alga Heterosigma akashiwo. J Plant Res 100:151-163

Harrison PJ, Waters RE, Taylor FJR (1980) A broad spectrum artificial seawater medium for coastal and open ocean phytoplankton. J Phycol 16:28-35

> Hayes KC, Lewitus AJ (2003) Nutrient responses of harmful algal blooms in South Carolina brackish lagoonal systems. J Phycol 39(S1):22-23

Heinbokel JF (1978) Studies on the functional role of tintinnids in the Southern California Bight. I. Grazing and growth rates in laboratory cultures. Mar Biol 47:177-189

> Herrero A, Muro-Pastor AM, Flores E (2001) Nitrogen control in cyanobacteria. J Bacteriol 183:411-425

Hiroishi S, Okada H, Imai I, Yoshida T (2005) High toxicity of the novel bloom-forming species Chattonella ovata (Raphidophyceae) to cultured fish. Harmful Algae 4: 783-787

Honjo T (1993) Overview on bloom dynamics and physiological ecology of Heterosigma akashiwo. In: Smayda TJ, Shimizu Y (eds) Toxic phytoplankton blooms in the sea. Elsevier, New York, p 33-41

Imai I, Ishida Y, Hata Y (1993) Killing of marine phytoplankton by a gliding bacterium Cytophaga sp., isolated from the coastal sea of Japan. Mar Biol 116:527-532

Imai I, Itakura S, Matsuyama Y, Yamaguchi M (1996) Selenium requirement for growth of a novel red tide flagellate Chattonella verruculosa (Raphidophyceae) in culture. Fish Sci 62:834-835

> Jeong HJ, Kim JS, Yoo YD, Kim ST and others (2003) Feeding by the heterotrophic dinoflagellate Oxyrrhis marina on the red-tide raphidophyte Heterosigma akashiwo: a potential biological method to control red tides using 
mass-cultured grazers. J Eukaryot Microbiol 50:274-282

Jeong HJ, Yoo YD, Kim JS, Kim TH, Kim JH, Kang NS, Yih WH (2004) Mixotrophy in the phototrophic harmful alga Cochlodinium polykrikoides (Dinophycean): prey species, the effects of prey concentration and grazing impact. J Eukaryot Microbiol 51:563-569

- Jeong HJ, Park JY, Rho JH, Park MO and others (2005a) Feeding by the red-tide dinoflagellates on the cyanobacterium Synechococcus. Aquat Microb Ecol 41:131-143

Jeong HJ, Yoo YD, Park JY, Song JY and others (2005b) Feeding by the phototrophic red-tide algal predators: five species newly revealed and six species previously known to be mixotrophic. Aquat Microb Ecol 40:133-150

> Jeong HJ, Yoo YD, Seong KA, Kim JH and others (2005c) Feeding by the mixotrophic algal predator Gonyaulax polygramma: mechanisms, prey species, the effects of prey concentration, and grazing impact. Aquat Microb Ecol 38:249-257

> Jeong HJ, Kim JS, Kim JH, Kim ST and others (2005d) Feeding and grazing impact of the newly described heterotrophic dinoflagellate Stoeckeria algicida on the harmful alga Heterosigma akashiwo. Mar Ecol Prog Ser 295:69-78

> Jeong HJ, Seong KA, Yoo YD, Kim TH and others (2008) Feeding and grazing impact by small marine heterotrophic dinoflagellates on heterotrophic bacteria. J Eukaryot Microbiol 55:271-288

Kana TM, Glibert PM (1987) Effect of irradiances up to 2000 $\mu \mathrm{E} \mathrm{m} \mathrm{m}^{-2} \mathrm{sec}^{-1}$ on marine Synechococcus WH7803: I. Growth, pigmentation, and cell composition. Deep-Sea Res A 34:479-495

Landry MR, Kirshtein J, Constantinou J (1996) Abundances and distributions of picoplankton populations in the central equatorial Pacific from $12^{\circ} \mathrm{N}$ to $12^{\circ} \mathrm{S}, 140^{\circ} \mathrm{W}$. DeepSea Res II 43:871-890

Li WKW (1998) Annual average abundance of heterotrophic bacteria and Synechococcus in surface ocean waters. Limnol Oceanogr 43:1746-1753

Livingston RJ (2007) Phytoplankton bloom effects on a gulf estuary: water quality changes and biological response. Ecol Appl 17:S110-S128

MacKenzie L (1991) Toxic and noxious phytoplankton in Big Glory Bay, Stewart Island, New Zealand. J Appl Phycol 3:19-34

Maranon E, Behrenfeld MJ, Gonzalez N, Mourino B, Zubkov MV (2003) High variability of primary production in oligotrophic waters of the Atlantic Ocean: uncoupling from phytoplankton biomass and size structure. Mar Ecol Prog Ser 257:1-11

Marshall JA, Nichols PD, Hamilton B, Lewis RJ, Hallegraeff GM (2003) Ichthyotoxicity of Chattonella marina (Raphidophyceae) to damselfish (Acanthochromis polycanthus): the synergistic role of reactive oxygen species and free fatty acids. Harmful Algae 2:273-281

Menden-Deuer S, Fredrickson KA, Strom SL (2008) Physical and biological drivers of HAB formation: rates of formation, persistence and decline of a Heterosigma akashiwo event in East Sound, Washington, USA. Abstr 13th Int Conf Harmful Algae, Nov 3-7, 2008, Hong Kong, p 87

Murrell MC, Lores EM (2004) Phytoplankton and zooplankton seasonal dynamics in a subtropical estuary: importance of cyanobacteria. J Plankton Res 26:371-382

Nagasaki K, Itakura S, Imai I, Nakagiri S, Yamaguchi M

Editorial responsibility: Robert Sanders,

Philadelphia, Pennsylvania, USA
(1996) The disintegration process of a Heterosigma akashiwo (Raphidophyceae) red tide in northern Hiroshima Bay, Japan, during the summer of 1994. In: Yasumoto T, Oshima Y, Fukuyo Y (eds) Harmful and toxic algal blooms. UNESCO, Paris, p 251-254

> Nielsen TG, Bjoernsen PK, Boonruang P, Fryd M and others (2004) Hydrography, bacteria and protist communities across the continental shelf and shelf slope of the Andaman Sea (NE Indian Ocean). Mar Ecol Prog Ser 274: 69-86

Nygaard K, Tobiesen A (1993) Bacterivory in algae: a survival strategy during nutrient limitation. Limnol Oceanogr 38: 273-279

> Oda T, Nakamura A, Shikayama M, Kawano I, Ishimatsu A, Muramatsu T (1997) Generation of reactive oxygen species by raphidophycean phytoplankton. Biosci Biotechnol Biochem 61:1658-1662

> Phlips EJ, Zeman C, Hansen P (1989) Growth, photosynthesis, nitrogen fixation and carbohydrate production by a unicellular cyanobacterium, Synechococcus sp. (Cyanophyta). J Appl Phycol 1:137-145

> Seong K, Jeong HJ, Kim S, Kim GH, Kang JH (2006) Bacterivory by co-occurring red-tide algae, heterotrophic nanoflagellates, and ciliates on marine bacteria. Mar Ecol Prog Ser 322:85-97

Shubin NH, Daeschler EB, Jenkins FA Jr (2006) The pectoral fin of Tiktaalik roseae and the origin of the tetrapod limb. Nature 440:764-771

Skovgaard A (1996) Engulfment of Ceratium spp. (Dinophyceae) by the thecate photosynthetic dinoflagellate Fragilidium subglobosum. Phycologia 35:490-499

Smayda TJ (1998) Ecophysiology and bloom dynamics of Heterosigma akashiwo (Raphidophyceae). In: Anderson DM, Cembella AD, Hallegraeff GM (eds) Physiological ecology of harmful algal blooms. Springer-Verlag, Berlin, p $113-131$

Spurr AR (1969) A low viscosity epoxy resin embedding medium for electron microscopy. J Ultrastruct Res 26: $31-42$

Stal LJ, Albertano P, Bergman B, Von Brockel K and others (2003) BASIC: Baltic Sea cyanobacteria. An investigation of the structure and dynamics of water blooms of cyanobacteria in the Baltic Sea - responses to a changing environment. Cont Shelf Res 23:1695-1714

> Stoecker DK (1999) Mixotrophy among dinoflagellates. J Eukaryot Microbiol 46:397-401

Sunda WG, Graneli E, Gobler CJ (2006) Positive feedback and the development and persistence of ecosystem disruptive algal blooms. J Phycol 42:963-974

Taylor FJR, Haigh R, Sutherland TF (1994) Phytoplankton ecology of Sechelt Inlet, a fjord system on the British Columbia coast. II. Potentially harmful species. Mar Ecol Prog Ser 103:151-164

Tillmann U, Reckermann M (2002) Dinoflagellate grazing on the raphidophyte Fibrocapsa japonica. Aquat Microb Ecol 26:247-257

Tilstone GH, Figueiras FG, Fraga S (1994) Upwelling-downwelling sequences in the generation of red tides in a coastal upwelling system. Mar Ecol Prog Ser 112:241-253

Vesk M, Moestrup O (1987) The flagellar root system in Heterosigma akashiwo (Raphidophyceae). Protoplasma 137: $15-28$

Submitted: February 16, 2009; Accepted: July 10, 2009

Proofs received from author(s): November 11, 2009 